Марија Опачић

Универзитет у Београду

Филолошки факултет

mayaopacic@gmail.com
УДК 811.161.1'367:811.163.41'367

https://doi.org/10.18485/slavistika.2020.24.2.9

оригинални научни рад примљено 24.03.2020.

прихваћено за штампу 18.09.2020.

\title{
СОЦИЈАТИВНЕ КОНСТРУКЦИЈЕ СА ДЕРИВИРАНИМ ВИШЕЧЛАНИМ ПРЕДЛОШКИМ ИЗРАЗИМА У РУСКОМ И СРПСКОМ ЈЕЗИКУ
}

\begin{abstract}
У раду се са синтаксичко-семантичког угла анализирају конструкције са социјативним инструменталом и вишечланим предлошким изразима у руском и српском језику у циљу осветљавања полицентричне структуре семантичке категорије социјативности и градуелности у изражавању значења друштва унутар њеног главног морфосинтаксичког центра. Појам деривирања предлошких израза поима се у његовом секундарном виду, што уједно представља разгранавање основне поделе предлога на неизведене и изведене сходно њиховом настанку. На тој подлози преиспитују се линеаризацијска организација, варирање тематско-рематских односа и стабилност статуса деривираних вишечланих предлошких израза у руском и српском језику с посебним освртом на социјативне конструкције рус. во главе $c(o)+N_{i n s t r}$, срп. на челу $c(a)+N_{\text {instr }}$, pyc. $c(o)+N_{\text {instr }}$ во главе, срп. $c(a)+N_{i n s t r}$ на челу и комуникативно истицање информације исказане постпонираним предлошко-падежним обликом у локативу рус. во главе, срп. на челу.
\end{abstract}

Кључне речи: социјативне конструкције, деривирани вишечлани предлошки изрази, секундарно деривирање предлога, фокализација, руски језик, српски језик.

The paper analyzes constructions with a sociative instrumental and multiple prepositional phrases in Russian and Serbian aiming at the explanation of the polycentric structure of the semantic category of sociativity and graduality in the expression of the sociative meaning with its main morphosyntactic-semantic point of view. The notion of the prepositional phrases derivation is conceived in the secondary meaning which represents the diversification of the basic division of prepositions to the non-derived and the derived forms according to their origin. The paper reconsiders the linear organization, the variation of the thematic-rhematic relations and the stability status of derived multiple prepositional locative phrase Russ. во главе, Serb. на челу with special emphasis on sociative constructions like Russ. во главе, Serb. на челу with the special emphasize on sociative constructions Russ. во главе c (o) $+N_{\text {instr }}$, Serb. на челу $c(a)+N_{\text {instr }}$, Russ. $c(o)+N_{\text {instr }}$ во главе, Serb. $c(a)+N_{\text {instr }}$ на челу are reconsidered.

Keywords: sociative constructions, derived multiple prepositional phrases, secondary prepositional derivation, focalization, Russian, Serbian.

1. Будући да смо о категорији социјативности, као једном од представника антропоцентричног категоријалног система, ${ }^{1}$ говорили у више наврата - и када су посреди радови мањег обима, у којима су у главним цртама приказане теоријско-методолошке поставке њеног (ин)варијантног испитивања (Опачић

${ }^{1}$ О антропоцентричном категоријалном комплексу в. у: Пипер и др. 2005: 592. О обради синтаксичке и семантичке категорије социјативности у руском и српском језику, као и о њеном дефинисању које објашњава њено место у антропоцентричној категоријалној целини в. у чланку: Пипер 2002: 19-29. 
2018а: 104-109) или њихова апробација у конфронтативно-типолошкој и монолингвалној синтаксичко-семантичкој анализи (Опачић 2018б: 67-78; Опачић 2019: 17-27) њене полицентричне структуре дифузног типа, ${ }^{2}$ и када се она посматра целовито током спровођења дисертационог истраживања о категоријалној социјативности у руском и српском језику-овога пута застаћемо код конструкција у којима се значење друштва изражава усложњавањем конструкција чији се полазни лик очитује у именском изразу са инструменталом и примарним ${ }^{3}$ предлогом рус. $c(o)$, срп. $c(a)$.

2. На почетку ћемо се укратко подсетити већ познатих полазишта, која су нам потребна за даље разматрање морфосинтаксичких и семантичких карактеристика социјатива са деривираним предлошким изразима. На првом месту, то је ослонац који при категоријалном одређењу социјативности имамо у синтаксичко-семантичкој докторској дисертацији М. Ивић о развоју значења инструментала у српскохрватском језику (Ивић 22005: 164), србистичкој синтаксичкој граматикографији (Пипер и др. 2005: 702), као и у типолошки оријентисаној монографији о комитативним конструкцијама (Архипов 2009: 97-99). Дакле, тиме су назначене водеће тачке међу постојећим бројним проучавањима саставних елемената категоријалних центара, које су битно утицале и на наше поимање социјативности у светлу облигаторних критеријума, у чијем се темељу налази дефинисање инваријантног значења друштва оличеног у градуелној истоветности семантичких функција несингулативних учесника категоријалне ситуације, као и у њиховој повезаности перцептивним јединством у свести говорног лица. ${ }^{4}$

3. На другом месту, то је полицентричност структуре анализиране семантичке категорије, у којој морфосинтаксички центар конструкција са социјативним инструменталом заузима доминантно место. Овом запажању, свакако, треба додати и напомену о његовој унутрашњој организацији, отелотвореној у варијантности, која напоредо са социјативно-реципрочним језгром подразумева и социјативна значења посредног типа изван њега, чији су маркери допуне социјативнореципрочног (нпр. рус. она встречается с ними, срп. она се среће с њима; рус. она разговаривает с ними, срп. она разговара с њима) и социјативног типа (нпр. рус. она путешествует с ними, срп. она путује с нима), које се у свом полазном прототипском облику јављају у именском изразу с неизведеним предлогом рус. $c(o)$, срп. $c(a)$. Заобилазећи овде даље упуштање у дистинкцију кумулативног и

${ }^{2}$ Појам дифузне структуре у организацији полицентричних или слабо центрираних поља наспрам својства компактности уводи А. В. Бондарко, при чему се његова употреба у овом чланку оправдава присуством већег броја језичких чињеница прелазне, разливене природе, те тешкоћом утврђивања граница простирања категоријалног центра и периферије (Бондарко 1984: 61-70). Такође, све наведено сведочи о неопходности разматрања проблематике социјативности у границама фази лингвистике, чија се природа детаљно објашњава и у монографији о фази појавама у језику (Радовановић 2015).

${ }^{3}$ В. о примарним и секундарним предлозима у руском језику у: Филин ред. 1979: 227.

${ }^{4}$ Овом приликом остајемо доследни категоријалном дефинисању социјативности предоченом у нашим пређашњим радовима које смо поменули на самом почетку овог чланка. 
некумулативног ${ }^{5}$ социјативно-реципрочног типа, сходно прерасподели семантичких улога учесника и реализацији обележја агентивности/пацијентивности, те блискости некумулативних социјатива и социјатива посредног типа, изнова указујемо и на факултативно обележје варијантног социјативног значења, које се у посматраном језгру конструкција са социјативним инструменталом остварује у виду неопходне узајамности и обостраног суделовања учесника у предметној ситуацији. Тиме је, разуме се, назначено и да се реципрочност сматра саставним делом категорије друштва сходно меродавности показатеља инваријантне социјативности и манифестовања варијантних, факултативних критеријума у социјативно-реципрочном појавном виду. Уп. кумулативне (1) и некумулативне социјативно-реципрочне конструкције (2) са социјативима посредне релације (3) у руском и српском језику.

1) Артур исчез в тумане, охая и вздыхая, а Колюня в это время снова обернулся к

Ане и встретился с ней глазами. (Алексей Варламов, Купавна, «Новый Мир»,

$2000)^{6}$

Артур је нестао у магли, јаучући и уздишући, а Кољуња се у то време поново окренуо према Ањи и срео се с њом очима. (превод Марија Опачић) ${ }^{7}$

2) Пред началом оперы, трагедии, балета, молодой человек гуляет [...],

разговаривает со всеми знакомыми и незнакомыми. (А. С. Пушкин, Мои замечания

об русском театре, 1820)

Пред почетак опере, трагедије, балета, младић шета [...], разговара с познаницима и

незнанцимма.

3) В детстве я много путешествовала с отц̧ом. (Евгений Гусятинский, Разньле

способы повзрослеть, «Русский репортер», 2010)

У детињству сам много путовала са оцем.

4. За нас је овом приликом посебно значајна чињеница да се градуелност, као одмеравање језичких датости према удаљености од прототипа, испољава у овом категоријалном центру, између осталог, и у предлошком деривирању конструкција са социјативним инструменталом и примарним предлогом рус. $c(o)$, срп. $c(a)$. Оно је, уопштено говорећи, карактеристично како за кумулативне и некумулативне социјативно-реципрочне конструкције, тако и за социјативе посредног типа.

${ }^{5}$ Редослед претходно наведених примера социјативно-реципрочних конструкција илуструје и опозицију кумулативност/некумулативност.

${ }^{6}$ Грађа потиче из Националног корпуса руског језика $<$ http://www.ruscorpora.ru/>. Ова напомена се односи и на друге примере уколико библиографски подаци не садрже електронску адресу другог извора.

${ }^{7}$ Напомена се односи и на превод осталих илустративних примера. 
Несумњиво важну улогу у идентификацији ових језичких чињеница у руском и српском језику има статус предлошке компоненте. Тако, на пример, лингвистичка славистичка енциклопедистичка издања разликују категоријалну, релациону, и лексичку, варијантну, семантику предлога, те се стога њихово саставно значење остварује спајањем речи, тј. лексичкограматичких јединица, за разлику од везника који релативност реализују повезивањем синтаксичких јединица, при чему се из вида не губи ни подела на примарне (нпр. $8, \kappa, c, \mu a$ ) и изведене (нпр. посредством, около) предлоге (Филин ред. 1979: 227). Као што је познато, предлози се и у руском и у српском језику срећу и у посебном облику, као проширени предлошки изрази, чија се градуелна својства у србистичкој нормативистичкој граматикографији уочавају и када они у реченици врше предлошке функције, карактеристичне за две основне класе предлога (Пипер, Клајн 22014: 206-207).

Предлошки изрази су, дакле, појава системског типа, и, осим уз инструменталске именске фразе с примарним и секундарним предлозима, могу се срести и с другим падежним формама и у руском и у српском језику, и то у три посебна појавна лика - нпр. с генитивом типа рус. в циелях (чего), срп. у цииљу (чега), рус. далеко от (кого, чего), срп. далеко од (кога, чега), рус. в отличие от (кого, чего), срп. за разлику од (кога, чега) итд. Лако се запажа да се трећа скупина у предлошком систему, коју илуструју секундарно деривирани предлошки изрази с двема или трима компонентама у њиховом саставу, може поделити према класификовању датих елемената сходно припадности другим врстама речи или броју основних предлога које садрже. ${ }^{8}$

5. Међу социјативима и у руском и у српском језику знатна је заступљеност конструкција са деривираним предлошким изразима, када се, по правилу, у препозицији именског израза с предлогом рус. $c(o)$, срп. $c(a)$ налази предлошко-падежна форма или прилошки елемент. У случају када адвербијална компонента има инхерентну социјативну вредност, она иступа и као модификатор и интензификатор значења друштва (1). Чак и уколико дата семантика изостаје, прилогом се може појаснити тип социјативног значења, нпр., квалификативним или темпоралним прецизирањем социјативног односа (2) или његовим аутосоцијативним ${ }^{9}$ маркирањем. В. социјативе са деривираним предлошким изразима у функцији глаголске (1-2) и именске допуне (3).

1) Город, куда собираются отправиться выпускники, а также само место будущей учебы они почти всегда выбирают вместе с родственниками, друзьями и

учителями. (Ю. Ф. Флоринская, Т. Г. Рощина, Жизненные планы выпускников школ из мальхх городов, «Человек», 2005)

Град у који намеравају да се упуте матуранти, као и само место будућих студија они скоро увек бирају заједно са рођаџчима, пријатељима и наставницима.

8 Литература бележи и ову појаву навођењем примера сложених социјативних конструкција супстантивног типа рус. в согласии с , срп. у складу $c, y$ сагласју $c$, на једној, и адвербијалног типа рус. вместе $c$, срп. заједно c, на другој страни (Филин ред 1979: 347).

${ }^{9}$ В. разлику између социјативности и аутосоцијативности у: Пипер 2002: 19-29; Пипер 1984-1985: 633-639. 
2) Параллельно с описанныли опытами, которые были проведены в нашей лаборатории [...] проходила еще одна серия опытов. (А. Н. Леонтьев,

Биологическое и социиальное в психике человека, 1981)

Паралелно с описаним експериментима који су спроведени у нашој лабораторији

[...] текла је још једна серија експеримената.

3) Статьи „другого Адамовича“ - это размышления наедине с собой, им можно предаться только в одиночестве. (Вадим Крейд, Георгий Иванов в Йере, «Звезда», 2003)

Чланци „другог Адамовича“ - то су размишљања насамо са собом, њима се човек може препустити само у самоћи.

Када је у препозицији примарног предлога рус. $c(o)$, срп. $c(a)$ предлошко-падежна форма са супстантивним елементом, социјативна модификација такође има два главна обележја и она су усклађена са интензификацијом значења друштва или пак њеним изостајањем уколико датој лексеми није својствено значење неодвојиве социјативности.

1) Программа «Государственный профессор России» может служить для научных сотрудников университетов, работающих в содружестве с научными

учреждениями РАН... (Программа развития РАН, В. Е. Фортова, Основные элементы программы, «За науку», 2013)

Програм „Државни професор Русије“ може служити научним сарадницима универзитета, који раде у заједници с научним установама РАН...

2) Силы добра представляли три богатыря во главе с Ильей Муромцем...

(Темныле силь против Масленицьь, «Народное творчество», 2004)

Силе добра су представљала три јунака на челу са Иљом Муромизем...

Грађа којом располажемо показује и да су поједини секундарно деривирани предлошки изрази у конструкцијама са социјативним инструменталом стекли статус устаљеног јављања, одвајајући под одређеним условима своју семантичку вредност од инваријантне социјативности у смеру исказивања других категоријалних значења, нпр. каузативног. Уп. примере (1-2).

1) Последние по времени мирные переговоры между Израилем и Сирией прервались в 2000 г. в связи с разногласиями по поводу судьбы Голанских высот. (Израиль вновь обвинил Сирию в пособничестве террористам, РБК, 2004)

Последњи по времену спровођења мировни преговори између Израела и Сирије прекинути су 2000. године због несугласища поводом судбине Голанске висоравни.

2) В связи с многочисленными обращениями налоговых органов по вопросу

правомерности применения [...] Министерство Российской Федерации по налогам и сборам сообщает следующее. (O порядке применения отдельных положений, 2004)

У вези с многобројним обраћањима пореских органа поводом правне заснованости примене [...] Министарство Руске Федерације за порезе и приходе саопштава следеће. 
6. Ако се, уз изузимање из даљег разматрања идиоматизованих облика и стилистичких ограничења њихове употребе, постави питање о постојаности линијске структуре секундарно деривираних предлошких израза, а последично и о актуализацији информације исказане адвербијалном или супстантивном компонентом, поред дезинтеграције секундарно деривираног предлошког израза, можемо такође, изнова, запазити и раније поменуту градуелност у изражавању значења друштва. Таква значења и средства за њихово исказивање групишу се на две стране, те су на једној случајеви у којима лексема која се постпонира примарном социјативу има инхерентно социјативно својство, док су на супротној страни примери у којима та вредност изостаје. У првој групи се исказивање социјативности помера у смеру истицања врсте социјативне релације или социјативног маркера и изражавања начина на који се она остварује рематизовањем одговарајућег сегмента (1'). У другој се, наиме, фокализује издвојени сегмент без додатног истицања значења друштва, при чему и друга врста карактеризације може бити социјативно свеобухватна (2’) или аутосоцијативна (3’). Уп. ове појаве код адвербијалног

1)' Город, куда собираются отправиться выпускники, а также само место будущей учебы они почти всегда выбирают с родственниками, друзьями и учителями вместе.

Град у који намеравају да се упуте матуранти, као и само место будућих студија они скоро увек бирају с рођацима, пријателима и наставницима заједно.

2)' C описанными опытами, которые были проведены в нашей Лаборатории [...] проходила еще одна серия опытов параллельно.

С описаним експериментима који су спроведени у нашој лабораторији [...] текла је још једна серија експеримената паралелно.

3)' Статьи „другого Адамовича“ - это размышления с собой наедине, им можно предаться только в одиночестве.

Чланци „другог Адамовича“ - то су размишљања са собом насамо, њима се човек може препустити само у самоћи.

и супстантивног постпонирања

1)’ Программа «Государственный профессор России» может служить для научных сотрудников университетов, работающих с научными учреждениями РАН в содружестве...

Програм „Државни професор Русије“ може служити научним сарадницима универзитета, који раде с научним установама РАН у заједници...

2)’ Силы добра представляли три богатыря с Ильей Муромщем во главе...

Силе добра су представљала три јунака са Иљом Муромием на челу...

7. Напоменимо и то да је овај проблем у лингвистичкој славистици одавно препознат, премда су истраживачи највише напора улагали у разматрање линеаризацијских карактеристика социјатива, чији деривирани предлошки изрази садрже супстантивну форму с предлогом без инхерентног социјативног обележја у препозицији. Тако су линијском реду у социјативним конструкцијама с предлошко-падежним спојем на челу већу пажњу посветили србистички стандардолошки, нормативистички прилози, мада ни у овом случају не можемо го- 
ворити о апсолутној унифицираности погледа на статус ове појаве у стандардном српском језику. ${ }^{10}$ У том погледу су посебно интересантне конструкције са именском допуном, чија управна реч нема социјативно-реципрочну семантику. Уколико, пак, социјативна конструкција има функцију именске допуне, детерминатора именског израза, који као целовит може иступати и у различитим синтаксичким функцијама, на пример, као субјекат или именски предикат, тада она прелази на периферију социјативних значења, прикључујући се псеудосоцијативима, чија се линијска организација, у целини, мора сагледавати трагом бројних семантичких типова, при чему је већина њих присутна у оба анализирана језика. В. примере (1-2) .

1) Госсекретарь США Джон Керри сообщил, что встреча групn во главе с РФ и США по Сирии пройдет в ближайшие день-два. (Лавров и Керри обсудили возобновление...., <http://www.ria.ru/>, 24.2.2016)

Државни секретар САД Џон Кери је саопштио да ће се сусрет група на челу ca РФ и САД по питању Сирије одржати у наредних дан-два.

2) По итогам пленума он дал интервью нескольким телеканалам и радиостанциям, в которых заявил, что «идеальное решение - это, конечно, создание

избирательного блока во главе с КПРФ...». (Рустем Фаляхов, Геннадий Зюганов «на троих» не делится, «Газета», 2003)

Поводом закључака пленума дао је интервју за неколико телевизијских канала и радио-станица у којима је изјавио да је «идеално решење, наравно, стварање изборног савеза на челу са КПРФ...».

Овде, пре свега, у виду треба имати семантичку спону ових конструкција са псеудосоцијативима карактеристичне појединости, уз напомену да оне у односу на њих, ипак, представљају атипичну појаву услед могућности означавања карактеристичног својства делом именског израза и у постпозицији и у препозицији, при чему се оправданост такве употребе заснива на премештању информационог фокуса, тј. на фокализацији компоненте којом се уз квалификацију изражава и спацијалност.

Укратко, рад је указао да при анализи сложених социјативних конструкција са деривираним предлошким изразима у обзир треба узети инваријантне и варијантне социјативне маркере, као и градуелност испољену у језгру главног морфосинтаксичког центра категорије социјативности, чије испитивање у крајњем кораку води и ка категоријалној периферији, одн. примерима у којима се прелазно значење темељи на обележјима која су блиска псеудосоцијативности.

${ }^{10}$ Тако, нпр., М. Телебак наводи следеће: „на челу - долази иза имена предводника: делегација с Марком Марковићем на челу “ (Телебак 2014: 194), што је подударно с препоруком о употреби прилога и прилошких одредаба (Ивић, Клајн, Пешикан, Брборић $\left.{ }^{5} 2011: 155\right)$, али не и с напоменом у синтаксичкој монографској публикацији (Пипер и др. 2005: 706). 


\section{Цитирана литература}

Архипов, Александр В. Типология комитативных конструкций. Москва: Знак, 2009.

[Arkhipov, Aleksandr V. Tipologiiā komitativnykh konstruktșiı̆. Moskva: Znak, 2009]

Бондарко, Александр В. Функциональная грамматика. Ленинград: Наука, 1984.

[Bondarko, Aleksandr V. Funktșional'naiā grammatika. Leningrad: Nauka, 1984]

Ивић, Милка. Значења српскохрватског инструментала и њихов развој, синтаксичко-семантичка студија. Београд, 1954. Београд: Београдска књига, Српска академија наука и уметности, Институт за српски језик САНУ, 2005.

[Ivić, Milka. Značenja srpskohrvatskog instrumentala i njihov razvoj, sintaksičko-semantička studija. Beograd, 1954. Beograd: Beogradska knjiga, Srpska akademija nauka i umetnosti, Institut za srpski jezik SANU, 2005]

Ивић, Павле, Иван Клајн, Митар Пешикан, Бранислав Брборић. Српски језички приручник. 5. издање. Београд: Београдска књига, Службени гласник, 2011.

[Ivić, Pavle, Ivan Klajn, Mitar Pešikan, Branislav Brborić. Srpski jezički priručnik. 5. izdanje. Beograd: Beogradska knjiga, Službeni glasnik, 2011]

Опачић, Марија. „Критеријуми диференцирања социјативних значења у руском језику“. Славистика књ. XXII, св. 2, 2018a: 104-109.

[Opačić, Marija. „Kriterijumi diferenciranja socijativnih značenja u ruskom jeziku“. Slavistika knj. XXII, sv. 2, 2018a: 104-109]

Опачић, Марија. „Квазипаралелне конструкције у савременом руском језику и њихови српски еквиваленти, на примеру категорије социјативности“. Зборник Матице српске за славистику 94, 20186: 67-78.

[Opačić, Marija. „Kvaziparalelne konstrukcije u savremenom ruskom jeziku i njihovi srpski ekvivalenti, na primeru kategorije socijativnosti““. Zbornik Matice srpske za slavistiku 94, 2018b: 67-78]

Опачић, Марија. „Међуоднос псеудосоцијативности и протосоцијативности у српском језику“. Наш језик L/1, 2019: 17-27.

[Opačić, Marija. „Međuodnos pseudosocijativnosti i protosocijativnosti u srpskom jeziku“. Naš jezik L/1, 2019: 17-27]

Пипер, Предраг. „Рronomina reflexiva у српскохрватском језику“. Зборник Матице српске за филологију и лингвистику XXVII/XXVIII, 1984-1985: 633-639.

[Piper, Predrag. „Pronomina reflexiva u srpskohrvatskom jeziku“. Zbornik Matice srpske za filologiju i lingvistiku XXVII/XXVIII, 1984-1985: 633-639]

Пипер, Предраг. „Проспект синтаксе руског језика у поређењу са српском, на примеру категорије социјативности“. Славистика VI, 2002: 19-29.

[Piper, Predrag. „Prospekt sintakse ruskog jezika u poređenju sa srpskom, na primeru kategorije socijativnosti“. Slavistika VI, 2002: 19-29]

Пипер, Предраг, Ивана Антонић, Владислава Ружић, Срето Танасић, Људмила Поповић, Бранко Тошовић. Синтакса савременога српског језика. Проста реченица. У ред. Милке Ивић. Београд: Институт за српски језик САНУ, Београдска књига, Нови Сад: Матица српска, 2005.

[Piper, Predrag, Ivana Antonić, Vladislava Ružić, Sreto Tanasić, Ljudmila Popović, Branko Tošović. Sintaksa savremenoga srpskog jezika. Prosta rečenica. U red. Milke Ivić. Beograd: Institut za srpski jezik SANU, Beogradska knjiga, Novi Sad: Matica srpska, 2005]

Пипер, Предраг, Иван Клајн. Нормативна граматика српског језика. 2. издање. Нови Сад: Матица српска, 2014.

[Piper, Predrag, Ivan Klajn. Normativna gramatika srpskog jezika. 2. izdanje. Novi Sad: Matica srpska, 2014] 
Радовановић, Милорад. Фази лингвистика. Нови Сад, Сремски Карловци: Издавачка књижарница Зорана Стојановића, 2015.

[Radovanović, Milorad. Fazi lingvistika. Novi Sad, Sremski Karlovci: Izdavačka knjižarnica Zorana Stojanovića, 2015]

Телебак, Милорад. Језички одгонетник. Нови Сад: Прометеј, 2014.

[Telebak, Milorad. Jezički odgonetnik. Novi Sad: Prometej, 2014]

Филин, Федот П. (ред.) Русский язык. Энциклопедия. Москва: Советская энциклопедия, 1979.

[Filin, Fedot P. (red.) Russkiı̌ iāzyk. Ėntșiklopediiā. Moskva: Sovetskaiā èntşiklopediiā, 1979]

\title{
Извори
}

$<$ http://www.ria.ru/>

$<$ http://www.ruscorpora.ru/>

\section{Мария Опачич}

\section{СОЦИАТИВНЫЕ КОНСТРУКЦИИ С ПРОИЗВОДНЫМИ МНОГОЧЛЕННЫМИ ПРЕДЛОЖНЫМИ ВЫРАЖЕНИЯМИ В РУССКОМ И СЕРБСКОМ ЯЗЫКАХ}

\begin{abstract}
Резюме
В работе с синтаксико-семантической точки зрения анализируются конструкции с творительным социативным и многочленными предложными выражениями в русском и сербском языках в рамках изучения полицентрической структуры семантической категории совместности и свойства градуальности, характеризующего ее главный морфолого-синтаксический центр. Понятие производное предложное выражение связано с основным разделением предлогов на основании оппозиции производность/непроизводность и количеством членов, входящих в его состав. В работе рассматриваются линейные особенности и статус вторично производных предложных выражений в русском и сербском языках. Особое внимание посвящается состоянию социативных конструкций русск. во главе c(o) + Ninstr, серб. на челу c(a) + Ninstr, русск. $c(o)+$ Ninstr во главе, серб. $c(a)+$ Ninstr на челу, линейному порядку формы русск. во главе, серб. на челу, а также типологии значения главного слова.

Ключевые слова: социативные конструкции, производные многочленные предложные выражения, вторичная производность, фокализация, русский язык, сербский язык.
\end{abstract}

